\title{
Bird Assemblage and Preference to Tengger Sacred Trees: Conservation insights from Tengger Tribe, Indonesia
}

\author{
Agung Sih Kurnianto ${ }^{1}$, Živa Justinek ${ }^{2}$, Purnomo ${ }^{1}$, Jati Batoro ${ }^{1,3}$, Nia Kurniawan ${ }^{3}$ \\ 1Post-Graduate Program, Brawijaya University, Jl. Mt. Haryono 169 Malang 65145, Indonesia \\ ${ }^{2}$ Departement of Biology, University of Ljubljana, Kongresni trg 12 Ljubljana 1000, Slovenia \\ ${ }^{3}$ Department of Biology, Brawijaya University, Jl. Veteran 1 Malang 65145, Indonesia
}

\begin{abstract}
We investigated the bird composition and preference at visiting the sacred figs (Ficus sp.) and its adjacent area in two villages of Tengger tribe: Ngadas and Poncokusumo, Malang, Indonesia. We applied the point count method and the sacred tree became the center of point count circle. We recorded 16154 individual birds in 35 days of observation, consisted of 46 species and 24 families. The bird composition composed of 362 predators, 9452 insectivores, 6029 omnivores, 278 nectarivores, and 33 frugivores. The observed bird were recorded utilizing seedling (652 individuals), sapling (3122 individuals), pole (3440 individuals), perching on a tree (2782 individuals), and flying overs (6158 individuals). Most of the insectivores were recorded flying over, where this character is owned by Cave Swiftlet. Figs, as an important component at the sacred area, provides many important component that could support the bird life and regeneration process. The presence of sacred tree also improving the relation between birds and plants, higher than those in the urban area or natural forest, and resulted a positive impact to the sustainable system of its surrounding agriculture.
\end{abstract}

Keywords: Bird, fig, Bromo Tengger Semeru, Sacred area

\section{INTRODUCTION}

The sacred place of Tengger is an evident of traditional conservation created by local wisdom. The knowledge of bioculture provides an immeasurable facts in understanding the occuring ecological processes [1] and provides an overview of local efforts in protecting the environment [2]. The presence of Tengger tribe plays an important role on the conservation efforts in Bromo-TenggerSemeru National Park [3]. Tenggerese has a strong basic on implementing their role, as they assertively holding onto the ancestor's belief that described by Sanggar pamujan and Dhanyangan on their spatial concept [4]. Sanggar Pamujan located on the highest ground of the village and Dhanyangan is a sacred place for protecting water resources. This place becomes a place for praying and serving sesajen (the sacred food) in Tengger belief $[5,6]$. Both location is marked by the presence of an old Fig tree (Ficus sp.) that sacred by the Tengger tribe. Moreover, the Fig tree becomes the habitat for some species of birds. The canopy's cover reserves water $[7,8]$, insects, and fruits as food for bird [9] and creates an interesting relation as a microhabitat.

In this study, we investigated the bird's composition and preference on visiting the sacred Figs and its adjacent area in two villages of Tengger

\footnotetext{
Correspondence address:

Agung Sih Kurnianto

Email : agung.sih.kurnianto@gmail.com

Address : Brawijaya University, Jl. Mt. Haryono 169

Malang 65145, Indonesia
}

tribe. The bird diversity could represent the quality of environment and microhabitat visited by the birds [9]. The surrounding agricultural and settlement area are very susceptive on suppresing the bird community [10-13], or indeed synergize together [5-6, 14]. Therefore, this study becomes a great opportunity to record the relationship between plant-bird-human in the sacred tree of Tengger as a microhabitat.

\section{MATERIAL AND METHOD}

The survey area was located in two Tengger villages: Gubugklakah and Ngadas, Poncokusumo District, Malang Regency, East Java Province, Indonesia. Survey was conducted in May (dry season) and September (wet season), 2016. Five survey points were chosen to represent each microhabitat in three sacred sites that adjacent to agricultural and settlement area: Dhanyangan and Sanggar Pamujan in Gubugklakah village (Figs crown volume approximately $=1802 \mathrm{~m}^{3}, 1701 \mathrm{~m}^{3}$ ), Sanggar Pamujan in Ngadas (Figs crown volume approximately $=1781 \mathrm{~m}^{3}$ ) (Fig.1). As comparation, we also surveyed two sites that is not sacred by the tribe at the conventional field in Gubugklakah and Ngadas village. We applied point count method [15] with 4 observers at every cardinal point in each location to avoid repeated record (n observers $=20$ ).

The sacred tree became the center of point count circle $(r=20 \mathrm{~m})$, while Albasia Albizia chinensis (Gubugklakah) and Mountain Casuarina Casuarina junghuniana (Ngadas) were chosen as center point of conventional field. 


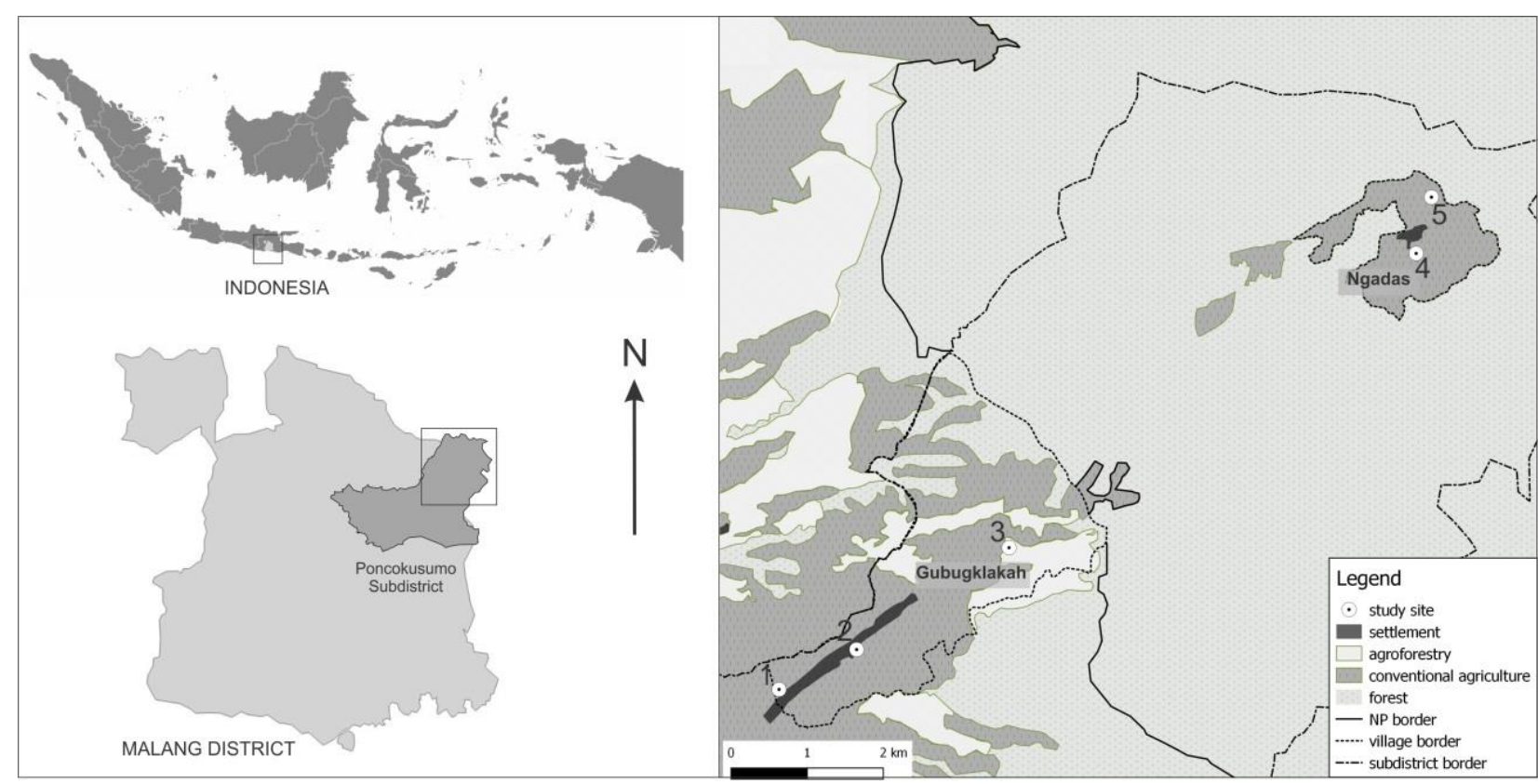

Figure 1. Map of study area. The numbered circles show the point count and clasification of sites. Key: 1= Gubugklakah conventional agriculture; 2=Dhayangan of Gubugklakah; 3=Sanggar Pamujan of Gubugklakah; 4=Ngadas Conventional agriculture; 5=Sanggar Pamujan of Ngadas.

The point count was used as the starting point for vegetation analysis in each sites, with four cardinal point (length $=20 \mathrm{~m}$ ). The result was visualized by the representment of the greatest usage of vegetation composition by the birds according to 4 classification: seedling (high: 0-1.5 $m$ ), sapling (high $\geq 1.5$ ), pole (diameter: $10-20 \mathrm{~cm}$ ), tree (diameter $>20 \mathrm{~cm}$ ), and fly overs. Survey was conducted everyday, started from 6 to 9 am as the highest diurnal activities of the birds, and avoided the rain, fog, and wind. We recorded the species, total individual, and behaviour that was observed visually.

The identification and inventarisation were classified according to the diet specialization and observation: mammals and birds (predator), insects and reptiles (insectivores), insects and plants (omnivores), and fruits (frugivores) [16]. The preference form and classification were represented by biplot analysis using PAST 3.14 Software. We used Nikon Aculon A30 8X25 binoculars to identify the bird and Canon EOS $1100 \mathrm{D}+300 \mathrm{~mm}$ canon lens to documenting. Identification was conducted by using field guide book [16].

\section{RESULT AND DISCUSSION}

We recorded 16154 individual birds in 35 days of observation, consisted of 46 species and 24 families. These consist of 362 predators, 9452 insectivores, 6029 omnivores, 278 nectarivores, and 33 frugivores. The observed bird were recorded utilizing seedling (652 individuals), sapling (3122 individuals), pole (3440 individuals), perching on a tree (2782 individuals), and flying overs (6158 individuals).

Insectivores dominated the result of this study. Most of the insectivores were recorded flying over $(57,17 \%$ of total insectivores) (Figure 2$)$, where this character is owned by Cave Swiftlet (5404 individuals). The other insectivores, such as Brown Prinia and Striated Grassbird, also found in smaller percentage, approximately $20.65 \%$ and $6.36 \%$ respectively. Both species and the other insectivore specialist were observed using various vegetation classification, including seedling, sapling, pole and tree, with the percentage of $2.02 \%, 3.65 \%, 12.65 \%$, and $11.24 \%$ respectively.

The Cave Swiftlet were found continuously flying in a circle, right above the figs tree (Figure 2A). Cave Swiftlet filters the insects by using its wide mouth as it flies [17]. Its unique anatomy, no gizzard in the esophagus, makes it continuosly filters the insects and immediately digests it [18]. Other than insects, Cave Swiftlet also interested on the water resources located under Dhanyangan. Cave Swiftlet has a unique behavior of drinking the raindrop or direct contact with water surfaces while flying [19]. Their behavior make them usually seen flying near the open water surface or flying in rainy or windy condition, in contrast with the other birds that avoid the physiological disadvantage when flying in the bad weather [20-21]. 


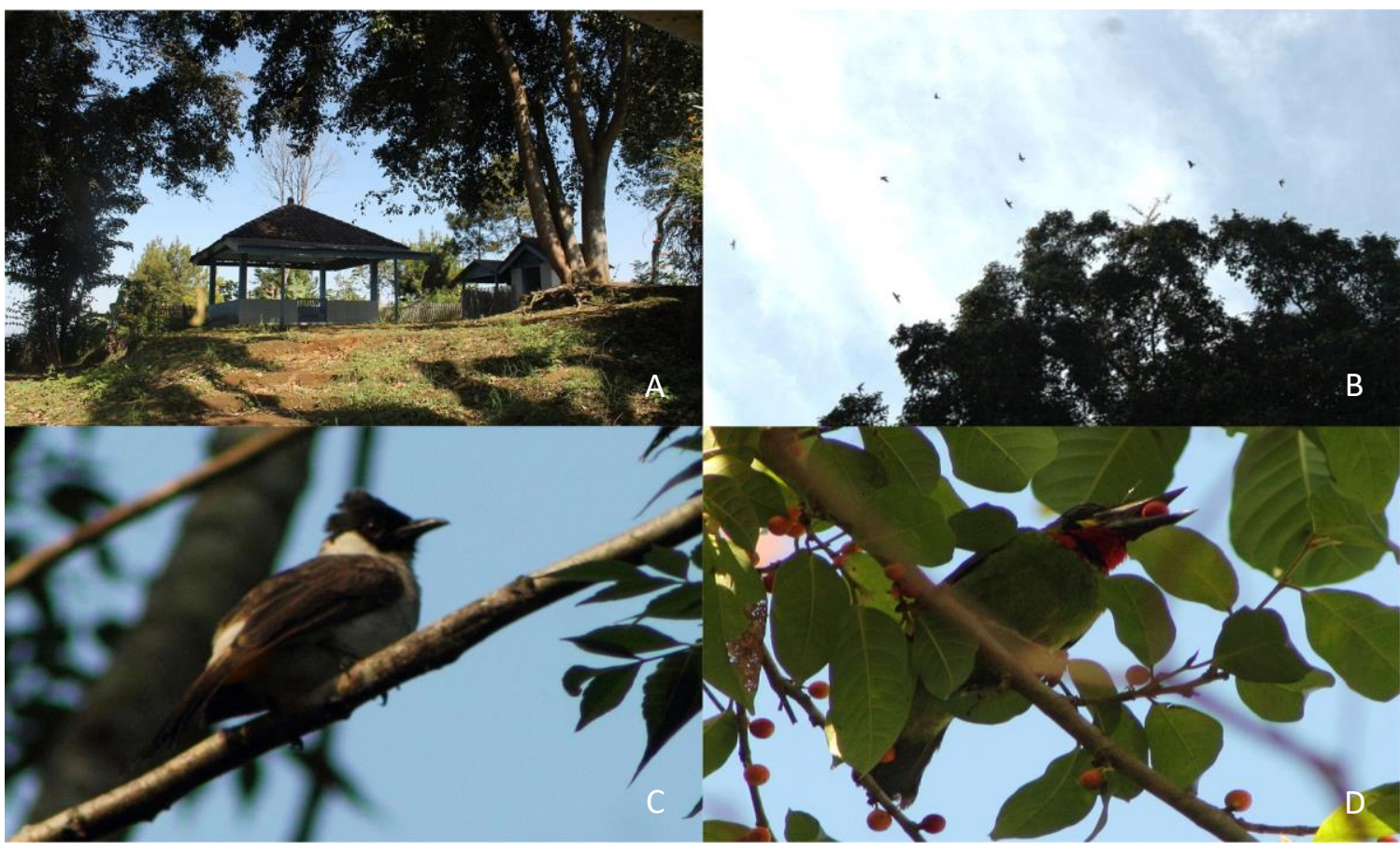

Figure 2. a) Sanggar Pamujan Gubugklakah; b) A flock of Cave Swiftlet Collocalia linchi; c) Sooty-headed bulbul Pycnonotus aurigaster; d) Black-banded Barbet Psilopogon javensis eating the fig fruit.

Omnivore was dominated by Sooty-headed Bulbul (73.92\%). Although most of the omnivores were found using pole (35.38\%), but they also utilizing the other vegetation equally, including seedling, sapling and tree with the percentage of $7.67 \%$, $30.38 \%$, and $26.47 \%$ respectively. Sooty-headed bulbul hunts insects in a group at agricultural area that (Figure $2 \mathrm{C}$ ) represented by seedling, sapling, and pole vegetation. The interesting fact was when the figs tree became fruitful, they would appear at tree classification with the community of frugivore bird (Figure 2D), which is the rarest specialist found during the observation $(0.20 \%)$. Sootyheaded bulbul also observed while mating or building a nest on figs tree (location 2). There was no competition aggression during the fruitful season of Figs tree. The other specialist, nectarivore, was only found in a small community during the observation, approximately $1.72 \%$. Nectarivores were mostly found while visiting pole (36.69\%) and tree (30.37\%).

Sooty-headed bulbul showing a great utilization of figs tree, such as mating, nesting, hunting, and socializing. They are mostly attracted with the figs fruit that temporally appear, in addition, as well as insects [9, 22-23]. However, their varies role and wide distribution on every type of vegetation make them able to compete with other specialist, such as insectivore and frugivore (Figure 3 ).
The observed bird was found to be higher in the sacred area with the average of 3319.67 , or $3.46 \%$ higher than those found in the non-sacred area. The average of visiting time on 5 survey points during the 35 days of observation were $82.03 \pm 23.26,90.63 \pm 29.07,87.88 \pm 34.90$, $94.94 \pm 27.51,106.31 \pm 47.90$, respectively. All birds found on the non-sacred area was also found on the sacred area. There was no feeding activity observed on the non-sacred tree, while the other activities were commonly observed, such as chirping and preening.

Figs, as an important component at the sacred area, provides many important role that could support the bird life and regeneration process [9]. Sooty-headed bulbul is an example of birds that utilizing Figs on suppporting their life until reproduction stage. Figs is chosen by Sooty-headed bulbul according to their preference on a tree that could support their offspring life, such as safety and feed availability [24]. The interesting fact is they undertake most of their avtivities on other vegetation that characterized as agriculture near the sacred area. This represents that the presence of sacred area is very profitable for the surrounding agriculture. The visit of insectivorous and omnivorous birds in all vegetation type represents their role in controlling insect pests on agriculture $[13,25]$ and helping on spreading the seeds [26] on the vacant and unproductive land. 


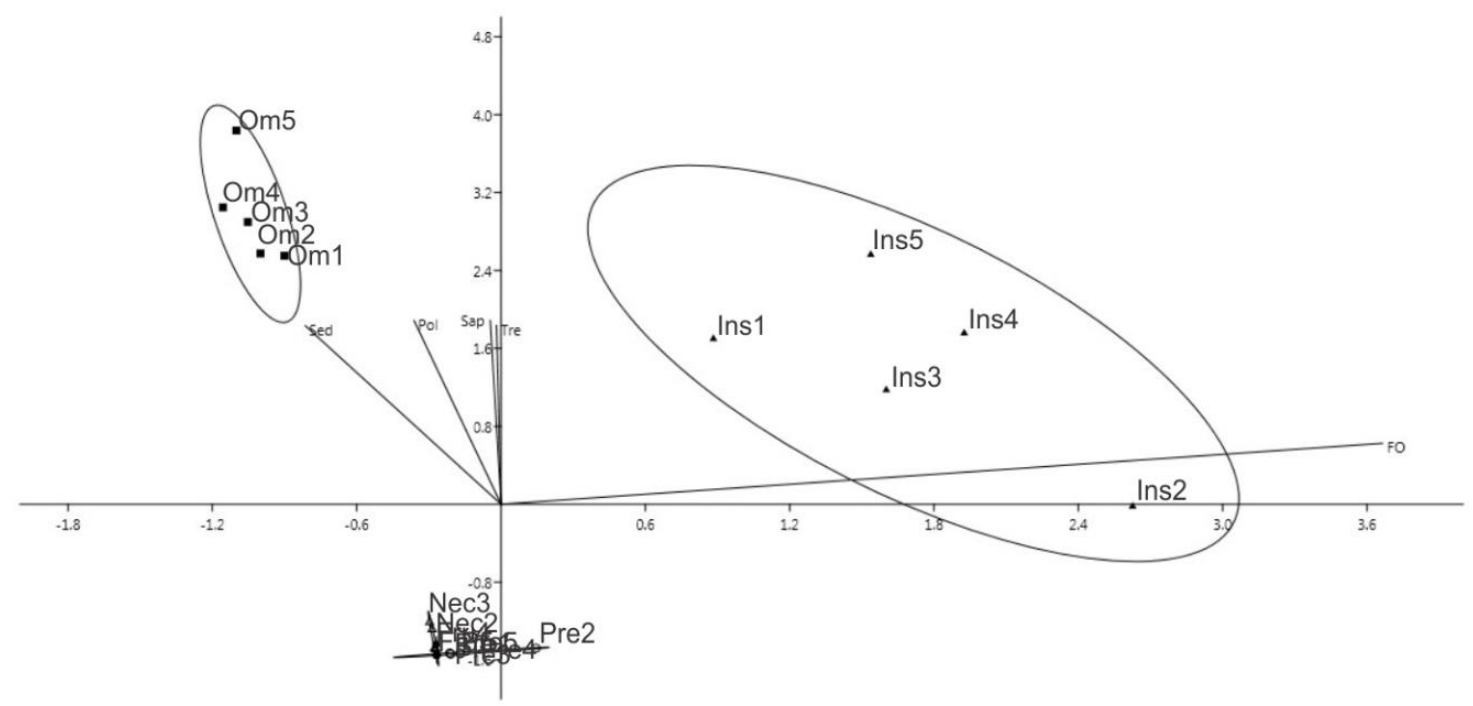

Figure 3. Biplot analysis of birds specialist prefention to vegetation type. The bird specialization was arranged in a code: Pre (Predator); Ins (Insectivore); Om (Omnivore); Nec (Nectarivore); Fru (Frugivore). Number at the dots represents the specialization on the survey sites.

The presence of sacred tree also improving the relation between birds and plants, higher than those in the urban area $[13,27]$ or even natural forest [9]. The competition among the urban niche users is very intense, while the resources is limited and reduced. Thus becomes one of the reasons that the bird community is highly susceptible. On the other hand, the natural forest is threatened by land degradation, including the figs tree that has long been known in supporting the bird life. The sacred tree has become a microhabitat that protected by culture. In addition, the ecological role and the protection from the sanctity itself have placed the tree as a sacred thing.

Figs takes an important role in the concept of Tengger culture. Every sacred place in Tengger is certainly has Figs tree as the representation of God's guarding in the society life and the nature. Therefore, the leaves of figs become an important part for wedding and traditional ceremony: Selamatan and Entas-entas [4]. Figs also known to have a role as water lifter [7], so that the tribe with their local knowledge conserving this tree intentionally, such as planted it near the water resources (Dhanyangan) and upland (Sanggar). This concept has worked by maintaining the water supply for the agriculture and settlement area located lower than the sacred figs. Interestingly, all that local knowledge has indirectly conserve the figs tree and the components inside the microhabitat to be able to work harmoniously.

\section{CONCLUSION}

We found that the sacred tree of Tengger tribe has a great potential as an effective conservation area. The presence of figs tree in a sacred location has given a protection and has conserved the bird diversity. This phenomenon is not easily to be found in other region and resulted a positive impact to the sustainable system of its surrounding agriculture. This becomes an important point on arranging the spatial policy, where maintaining the sacred tree would broaden the success of bird conservation and Tengger agriculture.

\section{ACKNOWLEDGEMENT}

We thank all the colleagues and students of biodiversity laboratory, Graduate Program of Brawijaya University. We also grateful to the Tengger tribe in Gubugklakah, Ngadas, for the accompaniment and assistance in the field. Special thanks to Perhutani (Persero), ranger of Bromo Tengger Semeru National Park, and Poncokusumo sub-district government for giving the permission, sharing information, and the accompaniment.

\section{REFERENCES}

[1]. O'Neill, A.R., H.K. Badola, P.P Dhyani,S.K. Rana. 2017. Integrating ethnobiological knowledge into biodiversity conservation in the Eastern Himalayas. Journal of Ethnobiology and Ethnomedicine. 13: 1-14.

[2]. Alves, R.R.N., R.C.L. Leite, W.M.S. Souto, D.M.M. Bezezza, A. Loures-Riberion. 2013. Ethno-ornithology and conservation in the semi-arid Caatinga of northeastern Brazil. Journal of Ethnobiology and Ethnomedicine. 9: 1-12.

[3]. Hakim, L. (2011). Cultural Landscapes of the Tengger Highland, East Java. In Landscape Ecology in Asian Cultures (pp. 69-82). Springer Japan.

[4]. Purnomo. 2013. Ngadas, Pesona Desa Adat Tengger. Galaxy Science. Malang. 
[5]. Suyitno. 2001. Mengenal Upacara Tradisional Masyarakat Suku Tengger. Satubuku. Surabaya.

[6]. Batoro, J., D. Setiadi, T. Chikmawati, Y. Purwanto. 2012. Pengetahuan Fauna (Etnozoologi) Masyarakat Tengger di Bromo Tengger Semeru Jawa Timur. Jurnal Biota. 17:45-54.

[7]. Nobel, P.S., M. Cui. 1992. Shrinkage of attached roots of opuntia ficus-indica in response to lowered water potentialspredicted consequences for water uptake or loss to soil. Annals of Botany. 70: 485-491.

[8]. Darmayanti, A.S., A.P. Fiqa. 2017. Canopy structure and its impact on hydrological performance of grown in the Purwodadi Botanic Garden. Journal of Tropical Life Science. 7: 40-47.

[9]. Sreekar R., N.T.P. Le, R.D. Harrison. 2010). Vertebrate assemblage ata fruiting fig (Ficus caulocarpa) in Maliau basin, Malaysia. Tropical Conservation Science. 3: 218-227.

[10]. Dunn, J.C., K.C. Hamer, T.G. Benton. 2015. Anthropogenically-Mediated Density Dependence in a Declining Farmland Bird. PLOS ONE.10(10): e0139492.

[11]. Harms, T.M., K.T. Murphy, X. Lyu, S.S. Patterson, K.E. Kinkead, S.J. Dinsmore. 2017. Using landscape habitat associations to prioritize areas of conservation action for terrestrial birds. PLOS ON.E 12(3): e0173041.

[12]. Guilherme, J.L., P.H. Miguel. 2013. Adaptation of Bird Communities to Farmland Abandonment in a Mountain Landscape. PLoS ONE. 8(9): e73619.

[13]. Seress, G., A. Liker. 2015. Habitat urbanization and its effects on birds. Acta Zoologica Academiae Scientiarum Hungaricae. 61: 373-408.

[14]. Cox, D.T.C., K.J. Gaston. 2016. Urban Bird Feeding: Connecting People with Nature. PLOS ONE. 11(7): e0158717.

[15]. Hostetler, M.E., M.B. Main. 2000. Point Count Method for Surveying Birds. Florida Monitoring Program. IFAS Extennsion. Florida.

[16]. Mackinnon, J., K. Phillipps, B. van Balen. 2010. Burung-burung di Sumatera, Jawa, Bali, dan Kalimantan. Burung Indonesia. Bogor.

[17]. Lourie, S.A., D.M. Tompkins. 2008. The diets of Malaysian swiftlets. Ibis. 142: 596.

[18]. Novelina, E.S., A.S. Satyaningtijas, S. Agungpriyono, H. Setijanto, K. Sigit. 2009. Morphological study of the Oesophagus and Stomach of the Cave Swiftlets (Collocalia linchi). Indonesian Journal of Animal and Veterinary Sciences. 3:205-211.

[19]. Seow, E.K., B. Ibrahim, S.A. Muhammad, L.H. Lee, J. Lalung, L.H. Cheng. 2016. Discrimination between Cave and Housefarmed Edible Bird's nest based on major mineral profiles. Pertanika Journal of Tropical Agricultural Science. 39: 181-195.

[20]. Strawford, M.L., J.M. Watts, T.G. Crowe, H.L. Classen, P.J. Shand 2011. The effect of simulated cold weather transport on core body temperature and behavior broilers. Poultry Science. 90: 2415-2424.

[21]. Gautreaux, S.A. 1991. The flight behaviour of migrating birds in changing wind fields : radar and visual analyses. American Zoologist. 31: 187-204.

[22]. Sanitjan, S., J. Chen. 2009. Habitat and fig characteristics influence the bird assemblage and network properties of fig trees from Xishuangbanna, south-west China. Journal of Tropical Ecology. 25: 161170.

[23]. Bhatt, D., A. Kumar. 2001. Foraging ecology of Red-vented Bulbul Pycnonotus cafer in Haridwar, India. FORKTAIL. 17: 109-110.

[24]. Wee, Y.C. 2009. Observations on the behaviour of the yellow-vented bulbul Pycnonotus goiavier (Scopoli) in two instances of failed nesting. Nature in Singapore. 2: 347-352.

[25]. Speakman, J.R., J. Rydell, P.I. Webb, J.P. Hayes, G.C. Hays, I.A.R. Hulbert, R.M. McDevitt. 2000. Activity patterns of insectivorous bats and birds in northern Scandinavia $\left(69^{\circ} \mathrm{N}\right)$, during continuous midsummer daylight. Oikos Journal. 88: 7586.

[26]. Pizo, M.A. 2004. Frugivory and habitat use by fruit-eating birds in a fragmented landscape of southeast brazil. Ornitologia neotropical. 15: 117-126.

[27]. Scochat, E., S. Lerman, Fernández-Juricic. 2010. Birds in urban ecosystems: population dynamics, community structure, biodiversity, and conservation In Agronomy monograph 55, Urban ecosystem ecology. Edited by Aitkenhead-Peterson and $A$. Volder. USA. American Society of Agronomy.75-86. 
Appendix

Table 1. A complete list and individu number of birds in 5 study sites. Keys: 1=conventional agriculture of Gubugklakah, 2=Dhanyangan of Gubugklakah, 3=Sanggar Pamujan of Gubugklakah, 4=conventional agriculture of Ngadas, $5=$ Sanggar Pamujan of Ngadas

\begin{tabular}{|c|c|c|c|c|c|c|}
\hline Family & Species & 1 & 2 & 3 & 4 & 5 \\
\hline Accipitridae & Black Eagle Ictinaetus malaiensis & 8 & 8 & 13 & 49 & 13 \\
\hline Accipitridae & Chinese Sparrowhawk Accipiter soloensis & & 161 & & & \\
\hline Accipitridae & Japanese sparrowhawk Accipiter gularis & & 35 & & & \\
\hline Accipitridae & Crested serpent eagle Spilornis cheela & 24 & & 18 & & 18 \\
\hline Accipitridae & Crested honey buzzard Pernis ptilorhynchus & & & 16 & & \\
\hline Aegithinidae & Common lora Aegithina tiphia & & 14 & 3 & & 3 \\
\hline Alcedinidae & Collared Kingfisher Todiramphus chloris & 110 & 36 & 47 & 110 & 47 \\
\hline Apodidae & Pacific swift Apus pacificus & & & 4 & & \\
\hline Apodidae & Cave Swiftlet Collocalia linchi & 743 & 1048 & 1183 & 1243 & 1187 \\
\hline Apodidae & Edible-nest Swiftlet Aerodramus fuciphagus & 12 & & & 12 & \\
\hline Campephagidae & Pied triller Lalage nigra & & & 3 & & 3 \\
\hline Campephagidae & Sunda Minivet Pericrocotus miniatus & & & 60 & & \\
\hline Campephagidae & Small Minivet Pericrocotus cinnamomeus & 14 & & 165 & & 169 \\
\hline Cisticolidae & Olive-backed tailorbird Orthotomus sepium & 25 & 9 & 62 & 28 & 62 \\
\hline Cisticolidae & Common Tailorbird Orthotomus sutorius & 3 & 17 & 15 & 3 & 15 \\
\hline Cisticolidae & Brown Prinia Prinia poluchroa & 442 & 98 & 484 & 443 & 485 \\
\hline Cisticolidae & Bar-winged Prinia Prinia familiaris & 10 & 16 & & 10 & \\
\hline Cisticolidae & Plain prinia Prinia inornata & 35 & & & & \\
\hline Columbidae & Spotted Dove Spilopelia chinensis & 30 & 55 & 74 & 34 & 76 \\
\hline Columbidae & Ruddy Cuckoo-dove Macropygia emiliana & & & 13 & & 11 \\
\hline Cuculidae & Plaintive cuckoo Cacomantis merulinus & 11 & 7 & 5 & 11 & 7 \\
\hline Cuculidae & Rusty-breasted cuckoo Cacomantis sepulcralis & 25 & 22 & 52 & 23 & 50 \\
\hline Dicaeidae & Scarlet-headed flowerpecker Dicaeum trochileum & & 14 & & & \\
\hline Dicaeidae & Blood-breasted Flowerpecker Dicaeum sanguinolentum & & & 25 & & \\
\hline Estrildidae & Javan Munia Lonchura leucogastroides & 45 & 15 & 169 & 45 & 169 \\
\hline Hirundinidae & Barn Swallow Hirundo rustica & & & 16 & & \\
\hline Hirundinidae & Pacific Swallow Hirundo tahitica & 41 & 357 & & 41 & \\
\hline Hirundinidae & Striated Swallow Hirundo striolata & & 146 & & & \\
\hline Laniidae & Long-tailed Shrike Lanius schach & & & 6 & & 6 \\
\hline Locustellidae & Striated grassbird Megalurus palustris & 158 & 84 & 100 & 160 & 100 \\
\hline Megalaimidae & Flame-fronted barbet Psilopogon armillaris & & & 147 & & 149 \\
\hline Megalaimidae & Black -banded Barbet Psilopogon javensis & & & 19 & & 17 \\
\hline Megalaimidae & Coppersmith Barbet Psilopogon haemacephalus & & & 21 & & 23 \\
\hline Muscicapidae & Lesser Shortwing Brachypteryx leucophrys & & & 46 & & \\
\hline Nectariniidae & Olive-backed Sunbird Cinnyris jugularis & 27 & 76 & 23 & 24 & 23 \\
\hline Nectariniidae & Streaky-breasted Spiderhunter Arachnothera affinis & & & 5 & & \\
\hline Paridae & Great Tit Parus major & & & 76 & & 76 \\
\hline Passeridae & Eurasian tree sparrow Passer montanus & 278 & 504 & 6 & 278 & 6 \\
\hline Phasianidae & Green junglefowl Gallus varius & 4 & & & 4 & \\
\hline Picidae & Fulvous-breasted Woodpecker Dendrocopos macei & 9 & 12 & 31 & 9 & 31 \\
\hline Psittacullidae & Yellow-throated Hanging Parrot Loriculus pusillus & & & 3 & & 3 \\
\hline Pycnonotidae & Sooty-headed bulbul Pycnonotus aurigaster & 797 & 488 & 1182 & 808 & 1182 \\
\hline Pycnonotidae & Yellow-vented Bulbul Pycnonotus goiavier & & & & 150 & 150 \\
\hline Turnicidae & Barred Buttonquail Turnix suscitator & & & 5 & & \\
\hline Zosteropidae & Oriental white-eye Zosterops palpebrosus & & & 12 & & \\
\hline Zosteropidae & Mountain white-eye Zosterops montanus & & & & 13 & 13 \\
\hline
\end{tabular}

